\title{
Methylprednisolone acetate induced release of cartilage proteoglycans: determination by high performance liquid chromatography
}

\author{
Herkko Saari, Riitta-Mari Tulamo, Yrjö T Konttinen, Timo Sorsa
}

\begin{abstract}
A high performance liquid chromatography (HPLC) procedure suitable for the simultaneous determination of the molecular size and concentration of macromolecular hyaluronate and proteoglycans in synovial fluid has been developed. Irrigation of the equine tarsocrural joint with $20 \mathrm{ml}$ physiological saline (PSS) caused a mild inflammation with an increase of proteoglycans in the synovial fluid over the baseline arthrocentesis control sample. Proteoglycan and hyaluronate in the synovial fluid did not interact to form hyaluronate-proteoglycan aggregates, but separated as distinct chromatographic peaks. This suggests that the cartilage derived proteoglycans in synovial fluid in the inflamed joint have been proteolytically cleaved from the non-covalent aggregates containing link protein and hyaluronate. Hyaluronidase digestion completely abolished the hyaluronate peak without affecting the proteoglycans. This seems to indicate that proteoglycan in synovial fluid is unable to interact with hyaluronate in synovial fluid to form cartilage type aggregates.
\end{abstract}

Proteolytic degradation and the time dependent release into the synovial fluid of such digested proteoglycan also resulted from the intra-articular injection of methylprednisolone acetate into normal tarsocrural joints and joints irrigated with PSS. These proteoglycans were insensitive to hyaluronidase but may consist of a protein moiety with attached glycosaminoglycans, as suggested by their sensitivity to proteinase and keratanase/chondroitinase digestion. These observations with cartilage treated with methylprednisolone acetate and mildly stimulated articular cartilage are inconsistent with earlier work on osteoarthritic and rheumatoid articular cartilage and have interesting implications for the pathogenesis and for the therapeutic action of intraarticular corticosteroids. A rapid HPLC procedure applicable to unprocessed small volume samples of synovial fluid gives information simultaneously on hyaluronate and proteoglycan in synovial fluid which is not attainable with immunoradiometric or isotope tracer techniques. It therefore appears to be useful for the analysis of cartilage turnover and destruction in health and disease.

Intra-articular injections of glucocorticoids have been widely used in the treatment of arthritis. Although their beneficial effect of relieving the acute inflammatory response is well docu- mented, reports of their influence on the metabolism of cartilage proteoglycans are still contradictory. Articular cartilage extracellular space is composed of at least four different proteoglycan populations, some of which are able to form aggregates with hyaluronate. ${ }^{1}$ In proteoglycan aggregates numerous proteoglycan subunits are non-covalently bound to a central strand of hyaluronate. The interaction is further stabilised by link proteins. ${ }^{2}$ The proteoglycan subunit consists of a central core protein to which glycosaminoglycan side chains are covalently bound. The core protein contains different regions for the attachment of chondroitin sulphate and keratan sulphate chains. The $\mathbf{N}$ terminal globular domain of the core protein possesses the ability to bind hyaluronate. ${ }^{34}$ The unique viscoelastic properties of the articular cartilage are mainly due to the strong water retention capacity of polyanionic proteoglycan aggregates. In addition, collagen fibres tend to oppose the considerable swelling pressure of hydrated proteoglycan aggregates.

The proteoglycan content of cartilage has been determined by various histochemical staining methods. Proteoglycan synthesis has been studied by monitoring the incorporation of ${ }^{35} \mathrm{SO}_{4}$ into the cartilage proteoglycans and its breakdown by following the appearance of labelled proteoglycans in the culture medium. ${ }^{56}$ Immunological methods have been developed for the determination of proteoglycans in synovial fluid, including several enzyme linked immunosorbent assays (ELISAs). ${ }^{78}$ Whether the effect of corticosteroids on the metabolism of proteoglycans in cartilage is anabolic or catabolic seems to be dependent on the experimental model systems or proteoglycan assay method, and is still largely uncertain.

The aim of this work was to develop a reproducible method for the simultaneous determination of large proteoglycans and hyaluronate in synovial fluid samples without any preceding sample preparation. It was intended to apply this method to determine the in vivo effects of intra-articular corticosteroids on cartilage glycosaminoglycan metabolism, using the equine tarsocrural joint as a model system.

\section{Materials and methods}

EFFECT OF INTRA-ARTICULAR

METHYLPREDNISOLONE ACETATE

One tarsocrural joint in five horses (Nos. 1, 2, 3,4 and 7) was injected at day 0 with $20 \mathrm{ml}$ physiological saline (PSS) to induce a slight inflammatory reaction. Twenty four hours after irrigation (day 1), the same joint was injected 
with $100 \mathrm{mg}(2 \cdot 8 \mathrm{ml})$ methylprednisolone acetate (MPA). Each injection was performed after taking a sample by the aseptic arthrocentesis technique. In addition, samples of synovial fluid were collected $2,3,4,7$, and 11 days after irrigation with PSS (table 1).

\section{CONTROLS}

In each of these horses, the contralateral joint was irrigated at day 0 and, instead of MPA, was injected on day 1 with $2.8 \mathrm{ml}$ PSS as a control. Three horses (Nos. 5, 6, and 8) had one tarsocrural joint subjected to repeated sampling only as an arthrocentesis control. In two of these (Nos. 6 and 8) the contralateral joint was irrigated with $20 \mathrm{ml}$ PSS on day 0 and injected with $2.8 \mathrm{ml}$ PSS on day 1 for comparison with similarly treated joints in horses injected with MPA. Three horses (Nos. 9, 10 and 11) were injected in one tarsocrural joint with $100 \mathrm{mg}$ of MPA without a preceding PSS injection to differentiate between the effects of PSS irrigation and injection.

\section{CLINICAL SIGNS}

The horses were observed for signs of lameness; exercise was restricted and they were kept at rest in their stalls. Clinically identifiable gross changes in the joints were evaluated at each synovial sampling by visual and manual examination.

\section{COLLECTION OF SYNOVIAL FLUID}

Synovial fluid samples were obtained using an aseptic technique before the injections (day 0 ), on day 1 ( 24 hours after irrigation) and on days $2,4,7$, and 11 after injection. Each sample was immediately transferred into a sterile test tube and centrifuged at $1500 \mathrm{~g}$ for 10 minutes to pellet the cells. The synovial fluid samples were stored without preservatives at $-20^{\circ} \mathrm{C}$ for HPLC analysis.

The synovial fluid volume was evaluated by forced aspiration into the syringe at each sampling time; $5 \mathrm{ml}$ was taken for further studies and the rest was carefully injected back into the joint. Total protein was determined by the method of Lowry et $a l^{9}$ and the leucocyte count was performed on a 1:20 dilution using a standard haemocytometer (Haemocytometer Counting Chamber, American Optical Corporation).
HIGH PERFORMANCE LIQUID CHROMATOGRAPHY The HPLC determination was performed using an LKB 2150 chromatographic pump (with a sample loop of $50 \mu \mathrm{l}$ ) coupled with an LKB 2151 online UV detector. ${ }^{10-12}$ Hyaluronate and proteoglycan in synovial fluid were detected at a wavelength of $206 \mathrm{~nm}$ and the chromatograms were recorded with an LKB 2220 recording integrator. The elution buffer was 50 $\mathrm{mM}$ sodium phosphate, $\mathrm{pH} 6.50$, and the constant flow rate was $1.0 \mathrm{ml} / \mathrm{min}$. TSK 5000 PW $(30 \mathrm{~cm} \times 7.5 \mathrm{~mm})$ and TSK $6000 \mathrm{PW}(60$ $\mathrm{cm} \times 7.5 \mathrm{~mm}$ ) size exclusion columns were obtained from Toyo Soda.

Synovial fluid samples were diluted to $1: 20$ to 1:40 with elution buffer, and $50 \mu \mathrm{l}$ was immediately injected into the HPLC apparatus.

\section{CALIBRATION OF THE COLUMNS}

For determination of the concentration of hyaluronate, a calibration graph was obtained using Healon (Pharmacia Diagnostica, S-75182) with the appropriate dilutions. The molecular weight calibration was performed as described by Saari. ${ }^{13}$ Proteoglycan concentrations in synovial fluid were calculated using Arteparon, a commercial proteoglycan mixture obtained from Luitpold-Werk.

The detection limits for hyaluronate and proteoglycans in synovial fluid were less than 5 $\mu \mathrm{g} / \mathrm{ml}$.

\section{CHEMICALS}

Hyaluronidase from Streptomyces hyalurolyticus (type IV), chondroitinase ABC from Proteus vulgaris and keratanase from Pseudomonas species (EC 3.2.1.103) were purchased from Sigma. MPA (Depo-Medrol $40 \mathrm{mg} / \mathrm{ml}$ ) was from Upjohn. Sodium chloride, $9 \mathrm{mg} / \mathrm{ml}$, was obtained from Orion $\mathrm{Oy}$. All other chemicals were of the highesr commercial purity available.

\section{Results}

DETERMINATION OF HYALURONATE AND

PROTEOGLYCAN IN SYNOVIAL FLUID WITH HPLC A single injection of MPA (100 mg) into the equine tarsocrural joint induced a progressive release of proteoglycan into the synovial fluid (fig 1, day 0-11). At the same time the hyaluronate content of the synovial fluid increased, but not to the same degree as the proteoglycan content. The peaks of hyaluronate and proteoglycan were easily separated from

Table 1 Experimental protocol for 105 synovial fluid samples

\begin{tabular}{|c|c|c|c|c|c|c|c|c|c|c|c|c|c|c|c|c|c|c|}
\hline \multirow[t]{3}{*}{ Day } & \multicolumn{18}{|c|}{ Horse (leg) } \\
\hline & \multicolumn{2}{|l|}{1} & \multicolumn{2}{|l|}{2} & \multicolumn{2}{|l|}{3} & \multicolumn{2}{|l|}{4} & \multicolumn{2}{|l|}{5} & \multicolumn{2}{|l|}{6} & \multicolumn{2}{|l|}{7} & \multicolumn{2}{|l|}{8} & \multicolumn{2}{|c|}{$9,10,11$} \\
\hline & Left & Right & Left & Right & Left & Right & Left & Right & Left & Right & Left & Right & Left & Right & Left & Right & Left & Right \\
\hline 0 & $\begin{array}{l}\text { PSS } \\
20\end{array}$ & $\begin{array}{l}\text { PSS } \\
20\end{array}$ & $\begin{array}{l}\text { PSS } \\
20\end{array}$ & $\begin{array}{l}\text { PSS } \\
20\end{array}$ & $\begin{array}{l}\text { PSS } \\
20\end{array}$ & $\begin{array}{l}\text { PSS } \\
20\end{array}$ & $\begin{array}{l}\text { PSS } \\
20\end{array}$ & $\begin{array}{l}\text { PSS } \\
20\end{array}$ & $S$ & - & $\begin{array}{l}\text { PSS } \\
20\end{array}$ & $S$ & $\begin{array}{l}\text { PSS } \\
20\end{array}$ & $\begin{array}{l}\text { PSS } \\
20\end{array}$ & $S$ & $\begin{array}{l}\text { PSS } \\
20\end{array}$ & - & - \\
\hline \multirow{2}{*}{$\begin{array}{l}1 \\
2,4,7,11\end{array}$} & $\begin{array}{l}\text { MPA } \\
100\end{array}$ & $\begin{array}{l}\text { PSS } \\
2 \cdot 8\end{array}$ & $\begin{array}{l}\text { PSS } \\
2 \cdot 8\end{array}$ & $\begin{array}{l}\text { MPA } \\
100\end{array}$ & $\begin{array}{l}\text { MPA } \\
100\end{array}$ & $\begin{array}{l}\text { PSS } \\
2 \cdot 8\end{array}$ & $\begin{array}{l}\text { PSS } \\
2 \cdot 8\end{array}$ & $\begin{array}{l}\text { MPA } \\
100\end{array}$ & $S$ & - & $\begin{array}{l}\text { PSS } \\
2 \cdot 8\end{array}$ & $S$ & $\begin{array}{l}\text { MPA } \\
100\end{array}$ & $\begin{array}{l}\text { PSS } \\
2 \cdot 8\end{array}$ & $S$ & $\begin{array}{l}\text { PSS } \\
2 \cdot 8\end{array}$ & $\begin{array}{l}\text { MPA } \\
100\end{array}$ & - \\
\hline & $S$ & $\mathrm{~S}$ & $\mathrm{~S}$ & $\mathrm{~S}$ & $\mathbf{S}$ & $S$ & $S$ & $S$ & $S$ & - & $\mathbf{S}$ & $\mathrm{S}$ & $S$ & $S$ & $S$ & $S$ & $S$ & - \\
\hline
\end{tabular}


each other and the other components of synovial fluid.

Hyaluronidase treatment of the synovial fluid sample (obtained at day 11) resulted in the complete disappearance of the hyaluronate containing peak, whereas the proteoglycan peak (retention time 15.52 minutes) was not affected by hyaluronidase treatment. If digestion was continued with protease or with a combination of chondroitinase $\mathrm{ABC}$ and keratanase, the proteoglycan peak was also degraded (lower curve in fig $2 \mathrm{~A}$ ).

The proteoglycan fraction was collected after hyaluronidase treatment from the terminal end of the HPLC capillary tube and further chromatographed on a TSK 5000 PW column. Figure $2 \mathrm{~B}$ shows the chromatogram obtained for the native, large molecular size proteoglycan (retention time 8.34 minutes) and the degradation products after subjection to chondroitinase $\mathrm{ABC}$ and keratanase (retention time 12.14 minutes). The lower curve shows chromatograms of pure chondroitinase $\mathrm{ABC}$ and keratanase enzymes; the results indicate that no marked interference with the determination of proteoglycans occurred.

EFFECT OF ARTHOCENTESIS, PSS IRRIGATION AND MPA ON THE CONCENTRATIONS OF HYALURONATE AND PROTEOGLYCAN IN SYNOVIAL FLUID

The injection of PSS into the joint induces a slight inflammatory reaction ${ }^{14}$ with concomitant leucocyte infiltration and an increase in the protein content in synovial fluid (table 2). In this model there was a slight increase of proteoglycans in the synovial fluid over the baseline concentration and arthrocentesis controls. Figure $3 \mathrm{~A}$ shows that this returned to the baseline concentration in seven days. The intra-articular injection of $100 \mathrm{mg}$ MPA on day

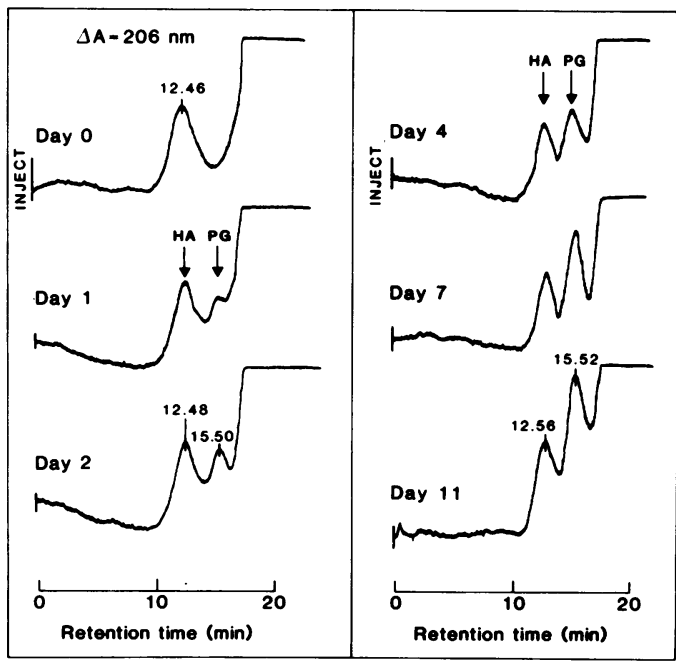

Figure 1 High performance liquid chromatography of equine tarsocrural joint synovial fluid. A mass of $100 \mathrm{mg}$ of methylprednisolone acetate (MPA) was injected intraarticularly at day 0 . A time course study of the effects of $M P A$ on proteoglycan $(P G)$ and hyaluronate $(H A)$ in synovial fluid was performed by drawing samples at days 0 , $1,2,4,7$, and 11. MPA induced a time dependent release of large molecular size proteoglycan into equine synovial fluid.

Hyaluronate and proteoglycan are eluted in different

fractions: hyaluronate at the retention times 12.46-12.56 and proteoglycan 15·50-15.52 minutes.

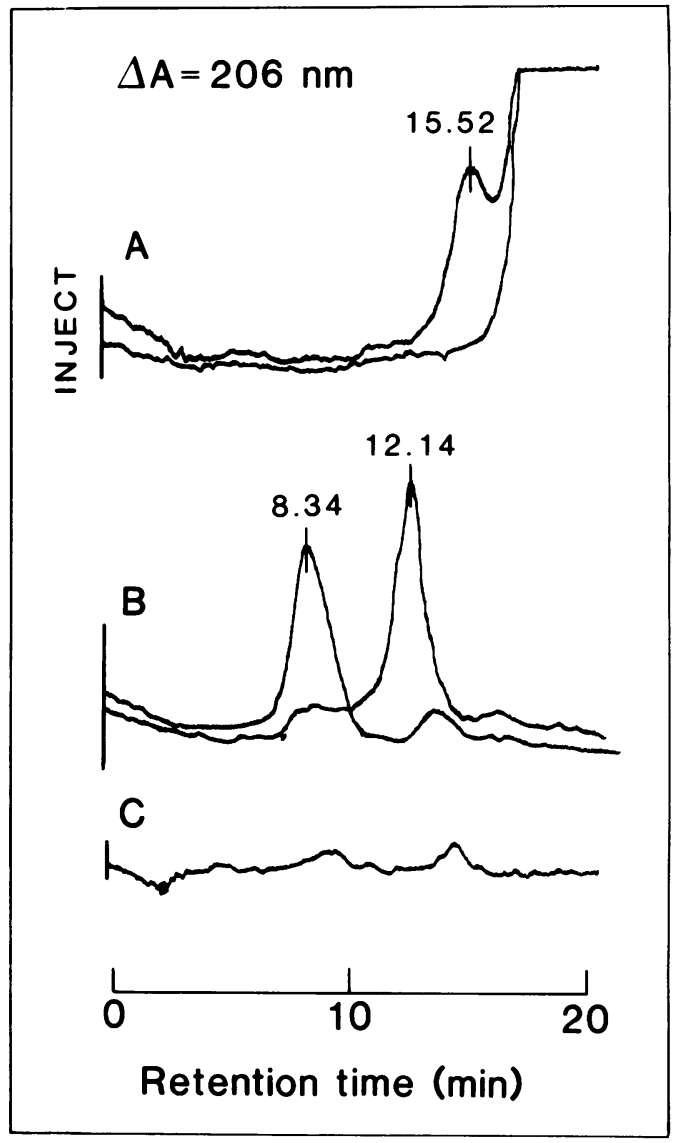

Figure 2 (A) HPLC chromatogram of equine synovial fluid after treatment with hyaluronidase;

hyaluronidase totally degrades the hyaluronate peak confirming its identity. The proteoglycan peak is not affected by hyaluronidase treatment (upper curve in A). However, if the incubation of the synovial fluid is continued after hyaluronidase treatment with a combination of chondroitinase $A B C$ and keratanase, the proteoglycan peak disappears (lower curve in $A$ ). (B) The proteoglycan peak with a retention time of 15.62 min on the TSK 6000 PW column was collected from the HPLC outlet. The proteoglycan fraction was further chromatographed on a TSK 5000 PW column due to its more advantageous range of linear resolution for proteoglycan and proteoglycan

degradation products. The proteoglycan peak elutes with a retention time of $8 \cdot 34$ minutes and its degradation products after digestion with chondroitinase $A B C$ and keratanase elute with a retention time $12 \cdot 14$ minutes. (C) Chondriotinase $A B C$ and keratanase were chromatographed alone without synovial fluid; this control shows that they do not interfere with the HPLC results for the proteoglycan fractions.

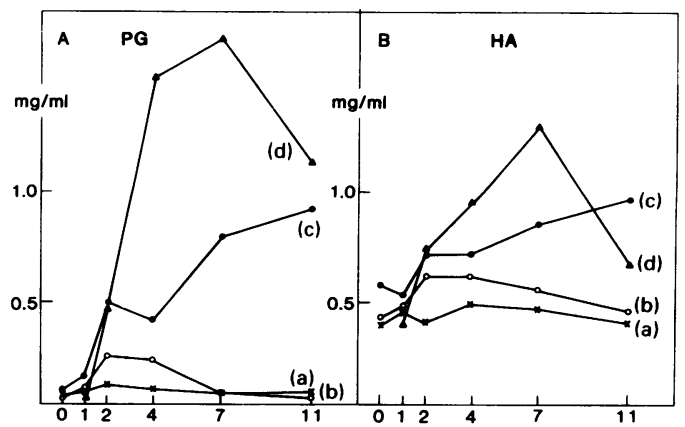

Figure $3(A)$ Equine proteoglycan $(P G)$ in synovial fluid and $(B)$ hyaluronate $(H A)$ in synovial fluid concentrations $(\mathrm{mg} / \mathrm{ml})$ in various experimental groups. Samples were collected on the days indicated. (a) Arthocentesis alone, $(n=3) ;(b)$ irrigation with physiological saline (PSS) $(n=7) ; P S S$ followed by (c) $100 \mathrm{mg}$ MPA intra-articularly one day after $P S S$ irrigation $(n=5)$ and $(d) M P A$ alone $(n=3)$. 
Table 2 Summary of results. Values given are mean (range) of sample of synovial fluid

\begin{tabular}{|c|c|c|c|c|c|c|c|c|c|c|}
\hline \multirow[t]{2}{*}{ Day } & \multicolumn{5}{|c|}{ Arthrocentesis $(n=3)^{*}$} & \multicolumn{5}{|c|}{$P S S$ irrigation $(n=7)^{*}$} \\
\hline & $\begin{array}{l}W B C \\
\left(\times 10^{9} / l\right)\end{array}$ & $\begin{array}{l}\text { Prot } \\
(m g / m l)\end{array}$ & $\begin{array}{l}\text { Vol } \\
(m l)\end{array}$ & $\begin{array}{l}P G \\
(m g / m l)\end{array}$ & $\begin{array}{l}H A \\
(m g / m l)\end{array}$ & $\begin{array}{l}W B C \\
\left(\times 10^{9} / l\right)\end{array}$ & $\begin{array}{l}\text { Prot } \\
(m g / m l)\end{array}$ & $\begin{array}{l}\text { Vol } \\
(m l)\end{array}$ & $\begin{array}{l}P G \\
(m g / m l)\end{array}$ & $\begin{array}{l}H A \\
(m g / m l)\end{array}$ \\
\hline 0 & $\begin{array}{l}0.05 \\
0.02-0.08\end{array}$ & $\begin{array}{l}11 \cdot 6 \\
2 \cdot 2-19 \cdot 0\end{array}$ & $\begin{array}{l}18 \cdot 0 \\
8 \cdot 0-28 \cdot 0\end{array}$ & $\begin{array}{l}0.02 \\
0-0.07\end{array}$ & $\begin{array}{l}0.36 \\
0.30-0.50\end{array}$ & $\begin{array}{l}0.17 \\
0.05-0.38\end{array}$ & $\begin{array}{l}10 \cdot 4 \\
3 \cdot 2-21 \cdot 2\end{array}$ & $\begin{array}{l}12 \cdot 0 \\
2 \cdot 5-19 \cdot 0\end{array}$ & $\begin{array}{l}0.02 \\
0-0 \cdot 14\end{array}$ & $\begin{array}{l}0.40 \\
0 \cdot 16-0.82\end{array}$ \\
\hline 1 & $\begin{array}{l}0.15 \\
0.02-0.33\end{array}$ & $\begin{array}{l}10 \cdot 3 \\
6 \cdot 3-15 \cdot 2\end{array}$ & $\begin{array}{l}16 \cdot 5 \\
8 \cdot 0-25 \cdot 0\end{array}$ & $\begin{array}{l}0.05 \\
0-0.09\end{array}$ & $\begin{array}{l}0.42 \\
0.28-0.50\end{array}$ & $\begin{array}{l}2 \cdot 02 \\
0 \cdot 10-6 \cdot 36\end{array}$ & $\begin{array}{l}16 \cdot 8 \\
6 \cdot 1-34 \cdot 0\end{array}$ & $\begin{array}{l}18 \cdot 0 \\
3 \cdot 0-25 \cdot 0\end{array}$ & $\begin{array}{l}0.05 \\
0-0.14\end{array}$ & $\begin{array}{l}0.45 \\
0.24-0.78\end{array}$ \\
\hline 2 & $\begin{array}{l}0.35 \\
0.16-0.67\end{array}$ & $\begin{array}{l}11 \cdot 1 \\
3 \cdot 6-15 \cdot 2\end{array}$ & $\begin{array}{l}17 \cdot 0 \\
6 \cdot 0-28 \cdot 0\end{array}$ & $\begin{array}{l}0.09 \\
0.04-0.14\end{array}$ & $\begin{array}{l}0.38 \\
0.22-0.52\end{array}$ & $\begin{array}{l}2 \cdot 50 \\
0 \cdot 31-9 \cdot 59\end{array}$ & $\begin{array}{l}15 \cdot 4 \\
4 \cdot 6-43 \cdot 2\end{array}$ & $\begin{array}{l}19 \cdot 5 \\
3 \cdot 0-34 \cdot 0\end{array}$ & $\begin{array}{l}0.22 \\
0-0.59\end{array}$ & $\begin{array}{l}0.59 \\
0.28-0.96\end{array}$ \\
\hline 4 & $\begin{array}{l}0.30 \\
0.04-0.72\end{array}$ & $\begin{array}{l}15 \cdot 0 \\
5 \cdot 8-31 \cdot 1\end{array}$ & $\begin{array}{l}17 \cdot 5 \\
4 \cdot 0-31 \cdot 0\end{array}$ & $\begin{array}{l}0.07 \\
0-0.18\end{array}$ & $\begin{array}{l}0.53 \\
0.40-0.72\end{array}$ & $\begin{array}{l}0.40 \\
0.02-1 \cdot 33\end{array}$ & $\begin{array}{l}14 \cdot 9 \\
7 \cdot 3-24 \cdot 6\end{array}$ & $\begin{array}{l}16 \cdot 3 \\
3 \cdot 5-23 \cdot 0\end{array}$ & 0.20 & $\begin{array}{l}0.5 \\
0.2\end{array}$ \\
\hline 7 & 0.34 & $15 \cdot 4$ & 18.0 & 0.06 & 0.44 & $0 \cdot 13$ & $12 \cdot 1$ & $14 \cdot 5$ & 0.0 & $\begin{array}{l}0.20 \\
0.53\end{array}$ \\
\hline 11 & $\begin{array}{l}0.13-0.68 \\
0.16 \\
0.04-0.23\end{array}$ & $\begin{array}{l}12 \cdot 3 \\
6 \cdot 2-20 \cdot 3\end{array}$ & $\begin{array}{l}4 \cdot 0-32 \cdot 0 \\
25 \\
13 \cdot 0-38 \cdot 0\end{array}$ & $\begin{array}{l}0-0.17 \\
0.05 \\
0-0 \cdot 16\end{array}$ & $\begin{array}{l}0.38-0.52 \\
0.37 \\
0.24-0.50\end{array}$ & $\begin{array}{l}0.05-0.27 \\
0.15 \\
0.03-0.38\end{array}$ & $\begin{array}{l}5 \cdot 1-18 \cdot 2 \\
10 \cdot 1 \\
5 \cdot 6-16 \cdot 0\end{array}$ & $\begin{array}{l}5 \cdot 0-25 \cdot 0 \\
13 \cdot 7 \\
4 \cdot 0-27 \cdot 0\end{array}$ & $\begin{array}{l}0-0.15 \\
0.03 \\
0-0 \cdot 18\end{array}$ & $\begin{array}{l}0.22-0.98 \\
0.43 \\
0 \cdot 22-0.84\end{array}$ \\
\hline
\end{tabular}

\begin{tabular}{|c|c|c|c|c|c|c|c|c|}
\hline \multirow[t]{2}{*}{ Day } & \multicolumn{5}{|c|}{$P S S$ irrigation $+M P A(n=5)^{*}$} & \multicolumn{3}{|c|}{$M P A(n=3)^{*}$} \\
\hline & $\begin{array}{l}W B C \\
\left(\times 10^{y} / l\right)\end{array}$ & $\begin{array}{l}\text { Prot } \\
(m g / m l)\end{array}$ & $\begin{array}{l}\text { Vol } \\
(m l)\end{array}$ & $\begin{array}{l}P G \\
(m g / m l)\end{array}$ & $\begin{array}{l}H A \\
(m g / m l)\end{array}$ & $\begin{array}{l}\text { Vol } \\
(m l)\end{array}$ & $\begin{array}{l}P G \\
(m g / m l)\end{array}$ & $\begin{array}{l}H A \\
(m g / m l)\end{array}$ \\
\hline $\mathbf{0}$ & $\begin{array}{l}0.09 \\
0.06-0.13\end{array}$ & $\begin{array}{l}9 \cdot 8 \\
5 \cdot 6-19 \cdot 2\end{array}$ & $\begin{array}{l}9 \cdot 6 \\
4 \cdot 0-20 \cdot 0\end{array}$ & $\begin{array}{l}0.07 \\
0-0.19\end{array}$ & $\begin{array}{l}0.63 \\
0.44-0.96\end{array}$ & - & - & - \\
\hline 1 & $\begin{array}{l}4 \cdot 36 \\
0 \cdot 05-8 \cdot 58\end{array}$ & $\begin{array}{l}20 \cdot 6 \\
10 \cdot 0-38 \cdot 2\end{array}$ & $\begin{array}{l}15 \cdot 1 \\
4 \cdot 5-35 \cdot 0\end{array}$ & $\begin{array}{l}0.13 \\
0-0.50\end{array}$ & $\begin{array}{l}0.66 \\
0.38-1 \cdot 12\end{array}$ & $\begin{array}{l}12 \cdot 5 \\
10 \cdot 0-15 \cdot 0\end{array}$ & - & $\begin{array}{l}0.36 \\
0.32-0.48\end{array}$ \\
\hline 2 & $\begin{array}{l}4 \cdot 46 \\
2 \cdot 80-7 \cdot 15\end{array}$ & $\begin{array}{l}20 \cdot 6 \\
8 \cdot 2-37 \cdot 0\end{array}$ & $\begin{array}{l}8 \cdot 3 \\
2 \cdot 0-13 \cdot 0\end{array}$ & $\begin{array}{l}0.47 \\
0-1 \cdot 17 \\
0.20\end{array}$ & $\begin{array}{l}0.86 \\
0.38-1.54\end{array}$ & $\begin{array}{l}10 \cdot 0 \\
8 \cdot 0-12 \cdot 0\end{array}$ & $\begin{array}{l}0.43 \\
0.28-0.75\end{array}$ & $\begin{array}{l}0.72 \\
0.42-0.96\end{array}$ \\
\hline 4 & $\begin{array}{l}0.63 \\
0.03-1 \cdot 02\end{array}$ & $\begin{array}{l}14 \cdot 0 \\
10 \cdot 1-16 \cdot 2\end{array}$ & $\begin{array}{l}10 \cdot 0 \\
4 \cdot 0-20 \cdot 0\end{array}$ & $\begin{array}{l}0.39 \\
0-0.84\end{array}$ & $\begin{array}{l}0.69 \\
0.40-0.96\end{array}$ & $\begin{array}{l}6 \cdot 5 \\
5 \cdot 5-8 \cdot 0\end{array}$ & $\begin{array}{l}1.48 \\
0.66-1.62\end{array}$ & $\begin{array}{l}0.94 \\
0 \cdot 70-1 \cdot 26\end{array}$ \\
\hline 7 & $\begin{array}{l}0.20 \\
0.10-0.30\end{array}$ & $\begin{array}{l}13 \cdot 4 \\
8 \cdot 2-18 \cdot 6\end{array}$ & $\begin{array}{l}6 \cdot 0 \\
1 \cdot 5-14 \cdot 0\end{array}$ & $\begin{array}{l}0 \cdot 77 \\
0 \cdot 19-1 \cdot 17\end{array}$ & $\begin{array}{l}0.85 \\
0.76-0.94\end{array}$ & $\begin{array}{l}5 \cdot 5 \\
3 \cdot 5-7 \cdot 5\end{array}$ & $\begin{array}{l}1 \cdot 65 \\
1 \cdot 22-1 \cdot 98\end{array}$ & $\begin{array}{l}1 \cdot 27 \\
0.98-1 \cdot 44\end{array}$ \\
\hline 11 & $\begin{array}{l}0.24 \\
0.07-0.42\end{array}$ & $\begin{array}{l}11 \cdot 6 \\
5 \cdot 6-19 \cdot 2\end{array}$ & $\begin{array}{l}4 \cdot 3 \\
1 \cdot 0-10 \cdot 0\end{array}$ & $\begin{array}{l}0.90 \\
0 \cdot 28-1 \cdot 33\end{array}$ & $\begin{array}{l}0.94 \\
0.62-1 \cdot 20\end{array}$ & $\begin{array}{l}7 \cdot 5 \\
4 \cdot 0-9 \cdot 5\end{array}$ & $\begin{array}{l}1 \cdot 10 \\
0 \cdot 82-1 \cdot 32\end{array}$ & $\begin{array}{l}0.64 \\
0.36-0.86\end{array}$ \\
\hline
\end{tabular}

${ }^{*}$ Abbreviations: (WBC) white blood cell count; (Prot) protein concentration; (Vol) volume of synovial fluid; (PG) proteoglycan concentration; (HA) hyaluronate concentration; (PSS) physiological saline solution; (MPA) methylprednisolone acetate.

1 did not reverse the effect of PSS irrigation, but caused an increased concentration of proteoglycan in the synovial fluid, this increase being at a maximum as late as 11 days after PSS injection. Interestingly, the injection of MPA without preceding irrigation with PSS produced an even higher and immediate appearance of large molecular size proteoglycans in the synovial fluid. The effect of MPA was at a maximum on day 7, after which it began to diminish. Figure $3 \mathrm{~B}$ shows that in all experiments the effect of MPA on the hyaluronate concentration in synovial fluid was fairly similar to the effect on proteoglycan, although the extent of the response was less (Fig 3B). These results show that MPA induces a degradative action on cartilage aggregates of proteoglycans.

Corticosteroids may cause rapid dehydration of the swollen joint. We therefore calculated the total concentrations of proteoglycan and hyaluronate in synovial fluid by taking into account the volume of synovial fluid.

Figure 4 shows the total concentrations of proteoglycan and hyaluronate in synovial fluid when the volume corrections were made. The PSS and PSS plus MPA induce an initial release of proteoglycans at nearly the same magnitude. When MPA was present, the proteoglycan content of synovial fluid remained at the constant high value throughout the observation period. MPA alone drastically increased the total proteoglycan concentration in synovial fluid, which reached its maximum value in four days, with a slight decrease towards the end of the follow up period.

The corresponding total determinations of hyaluronate in synovial fluid gave very different results. PSS and PSS plus MPA caused a

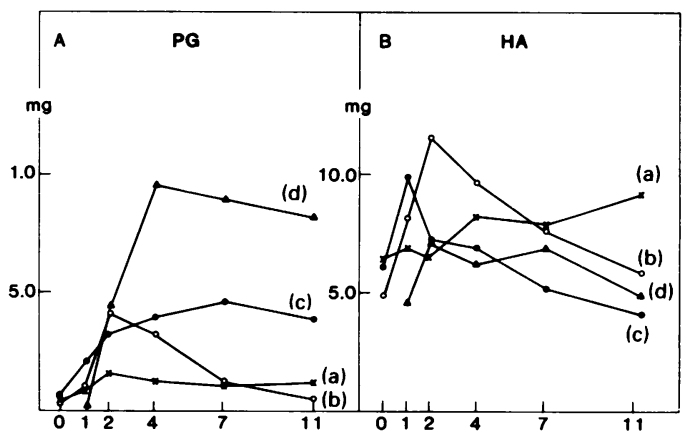

Figure $4(A)$ Total equine proteoglycan $(P G)$ and $(B)$ hyaluronate $(H A)$ in synovial fluid $(\mathrm{mg})$ in the experimental groups of fig 3. Calculations were based on the corresponding volumes of synovial fluid. The effect of $(a)$ arthrocentesis alone, (b) PSS irrigation, (c) PSS plus MPA and (d) MPA are shown.

moderate increase in hyaluronate in synovial fluid, but the hyaluronate concentration began to decrease at day 1 (MPA) and day 2 (PSS plus MPA), reaching the original value during the sample collection period. MPA alone caused an increase in the total hyaluronate concentration, which remained constant until day 7 , whereafter it fell and reached the original level on day 11. The increase of total hyaluronate in synovial fluid with PSS irrigation seems mainly to be due to the increased volume of synovial fluid (from a mean of $12.0 \mathrm{ml}$ to a maximum value of $19.5 \mathrm{ml}$ at day 2) and the simultaneous slight increase in hyaluronate concentration $(0.4 \mathrm{mg} / \mathrm{ml}$ at day 0 and $0.59 \mathrm{mg} / \mathrm{ml}$ at days 2 and 3 ). At the same time the protein content and leucocyte count increased in synovial fluid samples and decreased in parallel with the total hyaluronate concentration (table 2). Thus, it is reasonable to suggest that the slight inflammatory condition 
obtained with the injection of PSS causes first the stimulation of hyaluronate synthesis in synovial fluid, which then causes the retention of water in the joint resulting in an increased volume of synovial fluid. This was then followed by the reduction of hyaluronate synthesis to its basal level with a parallel volume depletion and decrease of total hyaluronate in synovial fluid to near the original value. In the experiments where MPA was injected after PSS the volume reduction occurred faster. Table 2 summarises the results obtained with this experimental method.

\section{Discussion}

Subunits of proteoglycan are released from articular cartilage into the synovial fluid from large hyaluronate-proteoglycan aggregates by the action of enzymes which digest the hyaluronate binding globular region from the proteoglycan core proteins. Two distinct metalloproteases, able to degrade proteoglycans, ${ }^{15}$ have been isolated from human articular cartilage. These matrix metalloproteases are secreted in the extracellular space in the zymogen form. They can be activated by organomercury compounds or by trypsin and their production is stimulated by interleukin $1 .^{16}$ They are zinc enzymes which require calcium for full activity. Neutral proteoglycan degrading enzymes from human articular cartilage have been identified as stromelysin. ${ }^{17}$ These cartilage matrix metalloproteinases may be involved in the MPA induced release of proteoglycan into the synovial fluid from normal or mildly irritated cartilage. This conclusion is indirect and is based on the inability of proteoglycan in synovial fluid spontaneously to aggregate with hyaluronate in synovial fluid and is supported by evidence provided by the insensitivity of the proteoglycan HPLC peak to hyaluronidase action.

In all joints treated with MPA the proteoglycan concentration in synovial fluid stayed considerably high during the sample collection period, indicating that the continuous degradation of cartilage matrix proteoglycan aggregates occurs during this time. The effects of MPA on the cartilage may occur over a long time, as methylprednisolone, the main metabolite of MPA, could be detected in synovial fluid even several weeks after a single intra-articular injection of MPA. ${ }^{18}$

To calculate the total amounts of hyaluronate and proteoglycan in synovial fluid, it was necessary to consider their concentrations with respect to the volume of synovial fluid on different days of sample aspiration. We used the forced aspiration of synovial fluid with simultaneous measurement of the synovial fluid volume. When measured with an isotopic technique, the mean equine tarsocrural joint fluid volume is $40 \mathrm{ml} .{ }^{19}$ Forced aspiration is not the most reliable method with which to measure synovial fluid volumes, because about $40 \%$ of the synovial fluid still remains in the joint cavity. ${ }^{20}$ However, if care is taken to aspirate at the same time of day, careful estimations of the volume of synovial fluid can be obtained.
Various histochemical staining methods have been used to assess the degenerative changes in the articular cartilage. For example, tissues have been stained using haematoxylin, eosin, toluidine blue and safranine $O .^{21-23}$ As a result, the formation of ulcers, loss of metachromasia, and cyst formation were observed as signs of proteoglycan degradation. ${ }^{21}$ The appearance of cartilage derived proteoglycans in the synovial fluid has been studied using several immunological techniques, including the use of antibodies against different molecular structures of proteoglycans. ELISA methods have been developed for the determination of proteoglycan core protein hyaluronate binding region ${ }^{24}$ and for extracted articular cartilage proteoglycans. ${ }^{8}$ Monoclonal antibodies have been used to determine keratan sulphate epitopes from synovial fluid. ${ }^{25}$ Many factors may influence the immunological methods, and these can affect the specificity and hamper the reliable determination of proteoglycans released in synovial fluid. Also, they do not give any information on the molecular size of the determined proteoglycan. We describe here a rapid HPLC procedure for the simultaneous assessment of the concentration and molecular size and form of hyaluronate and proteoglycan in synovial fluid. As this assay can be performed on unprocessed samples and less than $5 \mu$ of native synovial fluid is required, it is useful for the study of cartilage metabolism and destruction.

The HPLC chromatogram (fig 1) shows that the hyaluronate and proteoglycan fractions in the synovial fluid do not interact stably, as seen in cartilage, as their chromatographic peaks are eluted separately. This is probably due to the digestion of the hyaluronate binding region of the core protein by MPA induced matrix metalloproteases, which have been shown to be capable of degrading proteoglycan aggregates. The insensitivity of the proteoglycan peak to hyaluronidase treatment supports this suggestion. The proteoglycan peak may consist of proteoglycan subunits lacking the hyaluronate binding core protein domain. It is suggested that MPA in vivo causes the healthy equine articular cartilage to express proteolytic enzyme activity, which cleaves the hyaluronate binding region from proteoglycan aggregates and subsequently causes the release of proteoglycan subunits into the synovial fluid. This also suggests that normal cartilage turnover may be a proteinase mediated process.

In various tissue culture experiments corticosteroids have been shown to depress the degradation of cartilage derived from patients with osteoarthritis and rheumatoid arthritis by inhibiting the production of various inflammatory mediators and decreasing the activity of proteolytic enzymes. ${ }^{52-29}$ Corticosteroids have also been shown to decrease the concentration of proteoglycans in synovial fluid in the treatment of inflammatory joint diseases, being indicative for the decreased breakdown of cartilage proteoglycan aggregates. ${ }^{830}$

Using HPLC we were able to see the rapid release of large molecular size proteoglycans into synovial fluid during PSS induced irrigation. MPA alone or given intra-articularly at 
day 1 after PSS irrigation surprisingly increased the cartilage degradation as measured in terms of proteoglycan and hyaluronate concentrations in synovial fluid. We used the tarsocrural joint irrigated with PSS as an experimental model and there might be species differences in the action of MPA, but this seems unlikely. Considerable ethical reasons do not allow similar experiments to be performed on humans. The discrepancies between cartilage in normal subjects and patients with osteoarthritis or rheumatoid arthritis implies different modes of action of MPA. In patients with osteoarthritis and rheumatoid arthritis, MPA may induce lipomodulin gene activation ${ }^{31}$ and suppress the expression of, for example, the interleukin 1 gene in the well described conventional way. ${ }^{32}$ This might decrease the intrinsic and extrinsic degradation of cartilage extracellular matrix. In contrast, according to our findings, MPA increases the release of proteoglycan and hyaluronate into synovial fluid from normal or mildly stimulated cartilage. Whether this is due to some hitherto unrecognised alternative signal transduction pathway or is based on physicochemical properties of the MPA suspension is at present unknown.

1 Hardingham T E, Muir $\mathrm{H}$. Hyaluronic acid in cartilage and proteoglycan aggregation. Biochem 7 1974; 139: 565-81.

proteoglycan aggregation. Biochem $\mathrm{f} 1974 ; 139: 565-81$.
Hardingham T E. The role of link protein in the structure of cartilage proteoglycan aggregates. Biochem $\mathcal{f} 1979 ; 177$ : cartilage

3 Hardingham T E, Beardmore-Gray M, Dunham D G, Ratcliffe A. Cartilage proteoglycans. Ciba Found Symp 1986; 124: 30-46.

4 Paulsson M, Mörgelin M, Wiedemann H, et al. Extended and globular protein domains in cartilage proteoglycans. Biochem 7 1987; 245: 763-72.

5 Campbell M A, Handley C J, DeSouza S E. Turnover of proteoglycans in articular-cartilage cultures. Biochem $\mathcal{J}$ 1989; 259: 21-5.

6 Sledge C B, Steinberg J J. Co-cultivation models of join destruction. In: Dingle J T, Bordon J L, eds. Cellular interactions. In: Amsterdam: Blsevier/North-Holland, Biomedical Press, 1981: 263-80.

7 Heinegård D, Inerot S, Wieslander J, Lindblad G. A method for the quantification of cartilage proteoglycan structures liberated to the synovial fluid during developing degenerative joint disease. Scand $\mathcal{F}$ Clin Lab Invest 1985; 45: 421-7.

8 Saxne T, Heinegård D, Wollheim F A. Therapeutic effects on cartilage metabolism in arthritis as measured by the release of proteoglycan structures into the synovial fluid. Ann Rheum Dis 1986; 45: 491-7.

9 Lowry O H, Rosebourgh P J, Farr A L. Protein measurements with the Folin phenol reagent. $\mathcal{F}$ Biol Chem 1951; 193: 265-75.

10 Saari H T, Konttinen Y T, Santavirta S. Synovial fluid hyaluronate: a study using high performance liquid chromatography with size exclusion column. Medical Science Research 1989; 17: 99-101.

11 Saari H T, Konttinen Y T. Determination of synovial fluid hyaluronate concentration and polymerization by high performance liquid chromatography. Ann Rheum Dis 1989; 48: $565-70$

12 Saari H T, Konttinen Y T, Tulamo R M, Antti-Poika I, Honkanen $V$. Concentration and degree of polymerization of hyaluronate in equine synovial fluid. Am $\mathcal{F}$ Vet Res 1989 50: $2060-3$.

13 Saari H T. Oxygen derived free radicals and synovial fluid hyaluronate. Ann Rheum Dis 1991; 50: 389-92.

14 Wagner A E, McIlwraith C W, Martin G S. Effect of intraarticular injection of orgotein and sakine solution on equine synovia. Am F Vet Res 1982; 43: 594-7.

15 Woessner J F Jr, Selzer M G. Two latent metalloproteases of human articular cartilage that digest proteoglycan. $\mathcal{F}$ Biol Chem 1984; 259: 3633-8.

16 DiPasquale G, Caccese R, Pasternak R, Conalty J, Hubbs S Perry K. Proteoglycan- and collagen-degrading enzymes from human interleukin-1 stimulated chondrocytes from from human interleukin-1 stimulated chondrocytes from several species: proteoglycanase and collagenase inhibitors as potentially new disease-modifying anti-ar
Proc Soc Exp Biol Med 1986; 183: 262-7.

17 Gunja-Smith Z, Nagase H, Woessner J F Jr. Purification of the neutral proteoglycan-degrading metalloproteinase from human articular cartilage tissue and its identification as stromelysin matrix metalloproteinase-3. Biochem $\mathcal{F} 1989$; 258: 115-9.

18 Autefage A, Alvinerie M, Toutain P L. Synovial fluid and plasma kinetics of methylprednisolone and methylprednisolone acetate in horses following intra-articular administration of methylprednisolone acetate. Equine Vet $\mathcal{F}$ 1986; 18: 193-8.

19 Ekman L, Nilsson G, Persson L, Lumsden J H. Volume of the synovia in certain joint cavities in the horse. Acta Vet Scand 1981; 22: 23-31.

20 Rekonen A, Oka M, Kuikka J. Measurement of synovial fluid column by a radioisotope method. Scand $\mathcal{F}$ Rheumatol 1973; 2: 33-5.

21 Moskowitz R W, Davi W, Sammarco J, Mast W, Chasse $\mathrm{S} W$. Experimentally induced corticosteroid arthropathy. Arthritis Rheum 1970; 13: 236-43.

22 Chunekamrai S, Krook L P, Lust G, Maylin G A. Changes in articular cartilage after intra-articular injections of methylprednisolone acetate in horses. Am $\mathcal{f}$ Vet Res 1989; 50: 1733-41.

23 Gibson T, Burry H C, Poswillo D, Glass J. Effect of intraarticular corticosteroid injections on primate cartilage. Ann Rheum Dis 1977; 36: 74-9.

24 Witter J, Roughley P J, Webber C, Roberts N, Keystone E, Poole A R. The immunological detection and characterization of cartilage proteoglycan degradation products in synovial fluids of

25 Ratcliffe A, Doherty M, Maini R N, Hardingham T E. Increased concentrations of proteoglycan components in the synovial fluids of patients with acute but not chronic joint disease. Ann Rheum Dis 1988; 47: 826-32.

26 Hasty K A, Reife R A, Kang A H, Stuart J M. The role of stromelysin in the cartilage destruction that accompanies inflammatory arthritis. Arthritis Rheum 1990; 3: 388-97.

27 McGuire M K B, Meats J E, Ebsworth N M, Russell R G G, Murphy G, Reynolds J J. Effects of corticosteroids on cellular interactions in human tissues in cultures. In: Osteoarthritis symposium 1981. New York: Grune and Stratton, 1981: 138-9.

28 Pelletier J P, Cloutier J-M, Martel-Pelletier J. In vitro effects of tiaprofenic acid, sodium salicylate and hydrocortisone on of tiaprofenic acid, sodium salicylate and hydrocortisone on the proteoglycan metabolism of hum

29 Steinberg J J, Kincaid S R, Sledge C B. Inhibition of cartilage breakdown by hydrocortisone in a tissue culture model of rheumatoid arthritis. Ann Rheum Dis 1983; 42: 323-30.

30 Sedowick A D, Sin Y M, Moore A R, Edwards J C, Willoughby D A. Effects of local administration of hydrocortisone on cartilage degradation in vivo. Ann Rheum Dis 1984; 43: 418-20.

31 Hirata F, Schiffmann E, Venkatsubramanian K, Salomon D, Axelrod J. A phospholipase $\mathrm{A}_{2}$ inhibitory protein in rabbit neutrophils induced by glucocorticoids. Proc Natl Acad Sci USA 1980; 77: 2533-6.

32 Kern J A, Lamb R J, Reed J C, Daniele R P, Nowell P C. Dexamethasone inhibition of interleukin-1 beta production by human monocytes. $\mathcal{J}$ Clin Invest 1988; 81: 237-44. 